\title{
Conforming to intensive parenting ideals: willingness, reluctance and social context
}

\author{
Ciara Smyth and Lyn Craig
}

This is a post-peer-review, pre-copy edited version of an article published in Families, Relationships and Societies published as Smyth, Ciara and Craig, Lyn 'Conforming to intensive parenting ideals: willingness, reluctance and social context' Families, Relationships and Societies, Volume 6, Number 1, March 2017, pp. 107-124(18). The definitive publisher-authenticated version is available online at doi.org/10.1332/204674315X14393034138937

\section{Introduction}

Parenting and childhood are inextricably linked and a shift in one necessitates a shift in the other. It is argued that expectations of mothers intensified over the course of the twentieth century, culminating in an ideology of intensive mothering (Hays 1996), which many find difficult to meet (Walzer 1998, Coltrane 2000, Wall 2004, Wall 2010, Coleman, Ganong, and Warzinink 2007). This intensification of mothering/parenting is reflected in the changing landscape of childhood, with many suggesting that a cossetted childhood is the flipside of intensive parenting (Stearns 2003, Ehrenreich and English 2005, Chudacoff 2007, Cunningham 2006).

This paper looks at connections between the cultural shift towards intensive parenting and the changing character of childhood. It seeks to explore the extent to which compliance with intensive parenting ideals is an active choice and/or simply a reaction to the shifting social landscape. It begins by tracing the intensification of parenting over the twentieth century, and reviews the changing context of childhood. It draws on qualitative interview data to explore parents' perceptions of the differences between their children's childhood and their own. It adopts a social constructionist perspective and adapts West and Zimmerman's (1987) concept of 'doing gender'. Whilst others have applied this framework to studies of parenting, those studies have emphasised how parents fall into traditional gendered parenting roles. This paper adopts the 'doing parenting' framework to highlight how parents position themselves as 'good parents' with reference to dominant parenting discourse. It also explores how the social context of parenting influences how parents 'do parenting'.

Despite the gendered nature of contemporary parenting (Walzer 1998, Doucet 2009), the term 'intensive parenting' is increasingly used in the scholarly literature instead of 'intensive mothering' (Furedi 2001, Aurini and Davies 2005). Although the gender-neutral 'parenting' is inclusive but obfuscatory (a paper in itself), we follow others (Quirke, 2006, Bianchi et al. 2006, Wall 2010) and use the terms 'intensive mothering' and 'intensive parenting' interchangeably.

Beliefs about the proper care of children are, to a large extent, collectively produced (Duncan and Edwards 2003). Multiple factors shape and influence parenting attitudes and behaviours, including the market, workplace structures, economic and family policy, and the media. While Australia has distinctive features, it is usually grouped with the USA, the UK, Canada, and New Zealand as a "liberal" welfare state, in which work-family reconciliation and raising children are seen as largely private, not state, responsibilities (Orloff 2009, Gornick and Meyers 2003). Therefore, we draw on parenting literature from these countries to provide the context for this study and argue that the findings are likely pertinent to similar socio-political contexts. 


\section{History of intensive mothering/parenting}

Intensive mothering has origins in the sweeping changes ushered in by the Industrial Revolution (Coleman, Ganong, and Warzinink 2007). Changes in the organisation of paid and unpaid labour during the nineteenth century profoundly influenced ideas about parental roles and responsibilities. The shift from home production to a market economy took men out of the home to work for wages and fostered a belief in separate spheres for men and women, both physically and ideologically (Hays 1996). Men were situated in the public sphere and women in the private sphere, where responsibility for raising children was assigned to them (Hays 1996, Coltrane 2000).

Early in the twentieth century, breakthroughs in the physical sciences and discoveries in developmental psychology and psychoanalysis had a profound influence on socially desirable methods of child rearing. Experts warned mothers to be vigilant to their children's physical health and well-being. By the 1930s, Freudian psychologists introduced an emphasis on maternal love and affection to ensure psychological well-being (Coltrane 2000). Responsibility for both physical and psychological health meant mothers should devote themselves fully to the task of child rearing, laying the foundations for intensive mothering (Hays 1996, Coleman, Ganong, and Warzinink 2007).

Intensive mothering ideology strengthened further following the Second World War when mothers who had been caught up in the war effort were encouraged to exchange the workplace for the home (Hays 1996, Kociumbas 1997, Sanson and Wise 2001). Maternal deprivation and attachment theories in the 1950s-60s emphasised the importance of a prolonged period of infant-mother bonding to ensure optimal physical, psychological and intellectual development (Kociumbas 1997, Coltrane 2000). This redefinition of maternal responsibility 'vastly increased the child's demands on the mother' (Kociumbas 1997, 210). Curiously, as maternal responsibilities were expanding, maternal labour force participation began to increase, largely in response to the rising cost of living (Coltrane 2000, Ehrenreich and English 2005).

Despite the growth in maternal employment since the 1960s, the ideology of intensive mothering has persisted. Hays (1996) argues that intensive mothering is the dominant ideology of socially appropriate child rearing in the United States. It holds that 'children are innocent and priceless, that their rearing should be carried out primarily by individual mothers and that it should be centred on children's needs, with methods that are informed by experts, labour-intensive and costly' $(1996,21)$. The weight of this ideology, Hays argues, has transformed child rearing into 'a moral enterprise' $(1996,67)$. Contemporary fatherhood literature also draws attention to the emergence of the engaged father and the consensus is that today's fathers are more involved in their children's lives than previous generations (Glass 1998, Mannino and Deutsch 2007, Sayer, Bianchi, and Robinson 2004, Arendell 1997, Smith 2004). Yet there is ample evidence from time use research that, despite the growth in maternal employment, women still shoulder the bulk of responsibility for children (Monna and Gauthier 2008, Mannino and Deutsch 2007, Craig 2006, Doucet 2006, Nomaguchi, Milkie, and Bianchi 2005).

Many studies have drawn on intensive mothering ideology to investigate how it shapes discourse surrounding mothering/parenting and influences parenting practices. Scholars argue that it is the standard by which parents develop a sense of what it means to be a 'good mother' or 'good father' (Walzer 1998); it contributed to the growth in parenting magazines over the last two decades (Quirke 2006); it is endorsed in parenting discourse representing parents as needing expert advice and 
support (Widding 2014); and it has become 'the hegemonic discourse of motherhood' promoted by US maternal support organizations (Newman and Henderson 2014). Others have drawn on intensive parenting ideology to argue that it sheds light on the growth of homeschooling (Aurini and Davies 2005); that it 'serves as a means of social control, stigmatizing and punishing women who violate norms of motherhood' (Caputo 2007, 188); and that it is behind mothers' efforts to promote children's intelligence and accomplishment (Wall 2010). These studies attest to the power of intensive mothering ideology to shape parenting discourse and influence parents' practices and, given that parenting and childhood are two sides of the same coin, the intensification of parenting is mirrored in shifts in the terrain of childhood.

\section{Changing childhoods}

Over the twentieth century, children's innocence and vulnerability became a dominant theme in child-rearing advice literature. This emphasis has profoundly influenced the construction of 'good parenting', placing greater responsibility on parents to handle their fragile charges with care. Concern for children's physical and emotional vulnerability has resulted in 'paranoid parenting' (Furedi 2001), where parents accompany, supervise or hover around their children (Bianchi, Robinson, and Milkie 2006, Caputo 2007).

Zelizer (1985) argues that between 1870 and 1930 a profound transformation in how children were viewed occurred. During this period, she argues, their worth was no longer estimated in economic terms, but they became instead emotionally priceless, a transformation that has 'created an essential condition of contemporary childhood' $(1985,3)$. This cultural transformation emphasized children's emotional worth and by the mid-twentieth century family life was increasingly child-centred (Cunningham 2006, Chudacoff 2007, Wall 2004). This was reinforced over time as more effective contraception led to fertility decline and parents began investing more time and resources in fewer children (Furedi 2001, Bianchi, Robinson, and Milkie 2006).

A further development that significantly altered the character of childhood is the decline in children's independent, outdoor play. This has resulted in parents assuming greater responsibility for managing children's leisure (Chudacoff 2007, Furedi 2001, Stearns 2003). Changes in children's leisure over the twentieth century are inextricably linked with concerns for their safety and children's play was progressively drawn indoors (Zelizer 1985) (Cunningham 2006). Parental concern over outdoor play escalated from the 1960s (Chudacoff 2007, Cunningham 2006). Fears about 'stranger danger', abductions and abuse meant that many parents were increasingly reluctant to risk their children's safety. Although, statistically speaking, the number of children killed or abducted each year remains low and relatively unchanged from year to year, parental concern for children's safety can be linked to the widespread media coverage such cases get (Valentine 2004, Cunningham 2006, Furedi 2001), instilling fear in parents who consequently restrict their children's play in public space.

\section{Analytical framework}

The intensification of parenting and shifts in the landscape of childhood provide the backdrop for this paper. Our analytical framework incorporates a social constructionist perspective and draws insights from West and Zimmerman's (1987) concept of 'doing gender'. A social constructionist perspective takes the view that parenting is not the outcome of biological imperatives but that it 'entails various behaviors, skills and objectives learned through participation in the social community' (Arendell, $1999,3)$. Situated in time and place, the goals and objectives of parenting are regularly revised and redefined according to changes in social context. Norms and behaviours are reflexive and iterative. 
Factors that are intertwined with and influence parenting include: demographic changes, cultural norms and values, systems of stratification and shifts in societal organization and structure. Expectations of parents are subject to collective definition and are subject to reinterpretation and reconstruction (Arendell, 1999: 4).

For the purposes of this paper, a social constructionist perspective on parenting is enhanced by insights drawn from West and Zimmerman (1987). In their seminal paper, West and Zimmerman argue that "the "doing" of gender is undertaken by women and men whose competence as members of society is hostage to its production' (1987: 126). They argue that 'gender is not a set of traits, nor a variable, nor a role, but the product of social doings of some sort' (1987: 129), that it is created through interaction and also structures interaction. A key feature of doing gender is that individuals' performance as 'an incumbent of that category (i.e., gender) can be subjected to evaluation' (1987: 145). They stress how 'doing gender also renders the social arrangements based on sex category accountable as normal and natural, that is, legitimate ways of organizing social life' (1987: 146) As a result, if an individual fails to do gender appropriately, 'we as individuals - not the institutional arrangements - may be called to account (for our character, motives and predisposition)' (1987: 146).

Whilst others have applied this framework to parenting studies (Walzer 1998, Kurz 1997), they have sought to demonstrate how 'doing parenting' enshrines the gendered expectations associated with 'being a mother' and 'being a father'. Gender is indeed central to the performance of parenting, but in this paper, we are particularly concerned with exploring the performative aspect of parenting. Parenting is active; it involves enacting behaviours appropriate to one's status as a parent. To adapt the notion of 'doing gender' to parenting conceives of parenting as 'the product of social doings of some sort' (1987: 129). For contemporary parents, this 'some sort' we argue, is aligned with intensive parenting ideology, which now sits at the heart of normative understandings of the 'good parent' (Arendell 1997, Vincent 2010, Wall 2010, Newman and Henderson 2014). Whilst 'doing parenting' is enacted at the individual level, it is socially reproduced through interactions, reflexively constructed through the interplay of social norms embodied in individual actions. Dominant contemporary conceptions of 'doing parenting' encourage parents to uphold intensive parenting standards which are represented as normal and natural, which in turn obscures the factors that encourage conformity to intensive parenting ideology.

Numerous studies have highlighted how intensive mothering shapes the dominant parenting discourse and influences parenting practices. And while it is acknowledged that the values and practices enshrined within intensive mothering ideology set the bar impossibly high for many women (Coltrane 2000, Bianchi, Robinson, and Milkie 2006, Warner 2005), it is often implied that parents subscribe to intensive parenting ideals willingly. For example, Newman and Henderson (2014) report mothers' frustration with their inability to meet intensive mothering standards. Yet the support groups they attend promote intensive parenting ideology and encourage them to 'push through' $(2014,14)$ rather than question it. Similarly, although Wall $(2010)$ identified tensions and resistance to elements of intensive parenting ideology, she found that most of the middle-class mothers she interviewed engaged in highly intensive parenting. Few studies, however, explore parents' views on why they conform to intensive parenting ideals. Do they willingly subscribe to intensive parenting ideals or can other factors shed light on their responsiveness to intensive parenting ideology? This study addresses this gap by analysing parents' accounts of the factors that influence how they 'do parenting' and how they feel about the parenting standards they are expected to meet. 


\section{Method}

The findings presented here are drawn from a broader study that explored whether, why and how Australian parents try to foster their child's cognitive development in the preschool years. The social backdrop to the study was the intensification of parenting, a development reflected in the responsibilities rhetorically assigned to parents over the twentieth century. Not only are contemporary parents expected to nourish, shelter and attend to their children's physical and emotional needs, they are also deemed responsible for their intellectual development (Quirke 2006, Vincent and Ball 2007, Wrigley 1989, Furedi 2001). This message was further reinforced during the 1990s, 'the decade of the Brain' (Bruer 1999, 649), when 'new' research in the field of neuroscience identified infancy and early childhood as critical periods of development.

A component of this multi-method study included qualitative interviews with parents of preschoolaged children. The rationale for interviewing these parents was influenced by the 'first three years' movement (Macvarish, Lee, and Lowe 2014) that first received widespread media coverage in the 1990s (Bruer 1999, 649, Nadesan 2002, Quirke 2006, Furedi 2001, Wall 2004, Wall 2010, Bruer 1998b, Carnegie Corporation 1994, Hulbert 2004). A central claim was that the first three years of life represent a window of opportunity that parents must capitalise on if they wish to see their child succeed.

The sole criterion for inclusion in the interview component of the study was to be the parent of a preschool-aged child. During the interviews, parents were asked whether they considered themselves responsible for promoting their child's learning in the year/s before they start school, how and why they do so and the extent to which resources (educational, financial) influenced their practices. As class is a notoriously difficult concept to define and measure, parents' education level and income were used as proxies with a view to determining whether reported beliefs and practices varied by socio-economic status.

As the broader study explored an aspect of the intensification of parenting (promoting children's early learning), the purpose of asking parents to comment on how their childhoods differed to their children's was to gauge whether they perceived their parenting practices as being more 'intense' than those they experienced as children. Although this line of questioning probed childhood, the aim was to elicit parents' views about how changes in childhood influenced the way they 'did parenting'. The ensuing discussions proved to be revealing and are the subject of this paper.

\section{Sample}

To ensure the study sample was drawn from across the socio-economic spectrum, a purposive sampling approach (Silverman 2000) was adopted. Recruitment efforts centred on two local government areas (LGAs) of Sydney, Australia, one high socio-economic status, the other mixed socio-economic status, informed by a review of Australian Bureau of Statistics' indices of socioeconomic advantage and disadvantage (Australian Bureau of Statistics 2008).

An arm's length recruitment approach was utilized. Flyers were sent to childcare centres, a toy library, distributed at playgroups, mobile play centres, a library and neighbourhood centre. As per standard practice at the research centre through which the study was undertaken, participants were offered a $\$ 30$ gift voucher for their participation. The voucher was a drawcard for some participants in the mixed SES LGA, but less so in the high SES LGA. These efforts, combined with snowball sampling, yielded a total of twenty-nine participants. The final sample size was determined to ensure 
it comprised parents with a range of income and education levels and also by time and resource constraints.

Twenty-six of the participants were female. Eighteen were employed - the three fathers interviewed worked full-time while the 15 mothers who worked, did so part time. The main reason given for not undertaking paid work was taking care of children.

\begin{tabular}{llcc}
\hline Table 1: Participant characteristics & & High SES LGA & $\begin{array}{c}\text { Mixed SES } \\
\text { LGA }\end{array}$ \\
\hline Gender & & 12 & 14 \\
& Female & 1 & 2 \\
Lone parent & Male & 1 & 3 \\
Completed Yr 12 & Female & 12 & 11 \\
Bachelor degree or higher & Yes & 1 & 5 \\
& No & 11 & 3 \\
Annual household income $\$ \mathbf{1 0 0 K}$ & Yes & 2 & 13 \\
$\mathbf{+}^{\mathbf{1}}$ & & 7 & 2 \\
& No & 4 & 12 \\
NESB $^{\mathbf{2}}$ & & 0 & 2 \\
\hline
\end{tabular}

Twenty-three participants had completed high school and fourteen had a bachelor degree or higher. Nine participants who provided financial information had a combined annual household income of $\$ 100,000$ or more. Two spoke a language other than English at home. Most lived in couple households ( $n=25)$, with just four living in a lone-parent household (all mothers).

\section{Analysis}

Analysis was undertaken using the qualitative data analysis software, NVivo. All interviews were recorded and transcribed in full. The coding was informed by an extensive literature review and a content analysis (of parenting advice material) component of the study. After data were coded, Bazeley's (2009) three-step formula was adopted to describe, compare and relate the codes.

\section{Findings}

During the interviews, parents were asked whether they thought their child's upbringing was different to their own and whether they felt this was a change for the better or the worse. Although this line of questioning probed childhood, the aim was to elicit parents' views about how changes in childhood influenced the way they 'did parenting'. The key changes parents identified between their children's childhood and their own included: greater child-centeredness, children's lack of an unsupervised public life, changing conceptions of what constitutes a 'good childhood', discipline and a shift towards cognitively focused parenting.

\footnotetext{
${ }^{1}$ Four parents declined to provide this information.

${ }^{2}$ Non-English-speaking background.
} 


\section{Child-centeredness}

Greater child-centredness was identified by parents as a key generational shift between their children's childhood and their own. Most felt that the shift from a 'children-being-seen-and-notheard' mentality to one where children were afforded more respect, had more of a voice, and were the object of greater affection and attention was a change for the better. The belief that parenting should focus on the needs of the child is central to intensive parenting ideology.

Several parents contrasted their own upbringing, where obedience to parental authority was demanded, to that of their children. For these parents, a more child-centred style of parenting that respected children as individuals was a change for the better. This child-centred style involved listening to children, including them in discussions, spending more time with them and showering them with affection. Lucy, for example, described her childhood as 'very Victorian really', with a dominating father and a submissive mother. She contrasted her upbringing with that of her seven and four-year-old sons:

We were also talked about. It was always 'the girls' and I used to hate that. I try and not clump them together, they're both individual boys and I respect their opinions, so in that way it's very different.

Another quality of intensive parenting is its labour-intensive nature. This was illustrated by several mothers who said they spend more time with their children than their mother had with them. Two attributed this to how mothers in the past devoted more time to domestic duties:

She was just off ensuring the house was sparkling and off ironing and doing all sorts of things that I don't believe in. She had no time. (Amy)

The mother had to like do lots more stuff than what I have to... And there was more pressure on the mother to do it all, that the kids probably took more of a backseat - like playpens were... you know you had to clean cloth nappies. (Karen)

The increase in parental time with children was also noted as extending to fathers, with four parents highlighting greater father involvement as a significant generational change in parenting. None recalled spending much time with their own father when growing up and all contrasted this with their partner's involvement or their own parenting.

Despite the general endorsement of greater child-centredness, some parents highlighted some downsides. Rachel, for example, explained that she did not send her children out of the room when speaking with friends as her parents had. However, she noted challenges associated with this approach 'because then you can't have conversations with the other adults. I think it's better for the children, but worse for the parents [Laughs]'. For another parent, his children's right to express themselves freely undermined his parental authority: 'I think it's a change for the better for children ... But that makes my job ... harder because I think they kind of see themselves as equal to you.'

Other perceived downsides to child-centeredness included parental efforts to shield children from disappointment and their inability to deal with criticism later in life. Katy spoke of how comparing or singling children out was no longer acceptable and that instead 'everyone's a winner'. For Stephen, this attitude was best exemplified by the way the children's party game 'pass the parcel' had changed. 
When he played as a child, there was only one prize. The desire to shield children from disappointment has led to a modification whereby parents now ensure every layer contains a prize and no child misses out:

When you play pass the parcel these days, every kid has to get a present. We don't. Actually, no, Sarah did the last parcel; she put a bloody thing in everything. ...l think kids have to understand that you can't always win. And it's okay to not always win... because that's what life's like...

\section{Children's 'free' time}

In comparing their children's lives with their own childhoods, many parents spoke about how outdoor play was no longer safe without parental supervision. Many fondly recalled their own childhood when neighbourhood children played outdoors unsupervised for hours on end, returning home only when hungry or the streetlights went on. The key factor ruling out this unsupervised play was a fear child abduction and, to a lesser extent, concern about children negotiating busy roads. Some parents were without doubt that society was less safe, whereas others were not so sure but, as one parent put it, 'you have to operate on the premise that society is more unsafe.' [emphasis added].

The pervasive concern for children's vulnerability was a source of frustration for many parents. Some wrestled with the obligation to hover over their children constantly, with one mother contrasting her childhood freedom with that of her son:

I look at him and feel like I'm suffocating him. He's not even allowed in the front yard without an adult. The door is locked and he's not allowed to touch the key to open it. I just worry about what can happen and it's not worth the risk. (Annette)

Other frustrations included the implications that concern for children's vulnerability had for children's leisure time and ability to explore their own boundaries. Because her children could not enjoy the unsupervised free play she experienced as a child, Heidi was frustrated that 'everything has to be organised, you have to organise to have kids over so then you do it less.' Lucy also expressed concern that her children were not getting a chance to explore their own boundaries, because they were permanently under the watchful gaze of an adult. For this reason, she felt she ought to give her eldest child more freedom, yet felt conflicted by the obligation to persist in what Furedi (2001) describes as 'paranoid parenting'. The issue of giving children opportunities to test their limits was brought up by a parent who was annoyed by the removal of the monkey bars in his daughter's school. He ascribed their removal to fear of litigation if a child hurt themselves, but thought this was an overcautious approach not in children's best interests: 'If children don't hurt themselves they don't know their limits so they can't test their limits.'

\section{A 'good childhood'}

According to Hays (1996), intensive mothering is financially expensive, emotionally absorbing and labour-intensive. All of these elements featured in parents' accounts of what constitutes a 'good childhood' these days. Most felt their children had more cultural and entertainment experiences than they had, which included going to zoos, museums, concerts, and galleries. Reasons given for the contrast included greater affluence, the idea that children need certain experiences, and because children expect to be entertained. 
Miriam had completed high school and had an annual household income in the lowest quartile of the sample which, after paying the mortgage, left little disposable income. Nevertheless, she described how she and her husband were 'prepared to miss out on going to a movie or prepared to not buy a DVD' so that they could save to take their only child to a major musical production each year. For Miriam, it was important to 'give her a cultural experience'.

Parents generally endorsed the importance of keeping children entertained, but some also referred to the ratcheting up of children's expectations and that they are more indulged than in the past. In this respect, Heather alluded to the expectations that both she and her children held:

We're not content to just be at home and let the kids play in the garden all day. We seem to have this - and I'm as much to blame as anyone else - that the kids will say to me "Where are we going today?" It's an expectation.

For Caroline, greater affluence coupled with greater child-centeredness meant that her children experienced more than she did as a child:

They're a bit more spoilt than what they used to be... we didn't really have a whole heap of opportunities as much as what our kids will have... you know we didn't go to Seaworld or go on holidays. We went on holidays every year but we just went up to Foster and we went to the beach every day.

Cathy referred to a sense of obligation to keep her children entertained and the guilt she felt if she failed to do so:

We spend a lot of our weekends or the days I'm not a work, I take my kids everywhere. I feel actually guilty if I sit around doing nothing.

Parents' financial resources influenced how much they could engage in practices associated with 'concerted cultivation' (Lareau 2003, 2011). Although two-thirds of parents had their preschooler in a structured activity, children in the mixed SES LGA (which comprised a range of income and education levels) were less likely to be enrolled in activities than children in the high SES LGA.

When discussing the structured after-school activities her older son attended, Heidi described feeling very conflicted about whether it was necessary to give him a competitive advantage or whether she was actually putting him under increased pressure. She described the high SES LGA she lived in as a competitive one, where other children were doing up to four activities per week:

So are you disadvantaging your child by not having them in all these things or is it actually quite unhealthy that they are exhausted because they go from one... structured environment, jump in the car, chuck some food down them and off they go to their next structured environment, and then we've got to get the homework in and I just don't know how people do it. I really struggle with it.

Despite misgivings about her children's overscheduling, Heidi was the only parent who recognised that her children's lives needed to be more structured and organised because a fear of traffic and strangers meant they could not enjoy the free outdoor play that she had. By contrast, Cathy felt that 
her children's lives had to be more structured because she worked, unlike her own mother. Additionally, changing conceptions of what constitutes a 'good childhood' figure in her response, as she comments: 'parents these days want their kids to do as much, experience as much things as they [can].'

\section{Discipline}

In noting how parenting and childhood had changed, just under half of the parents mentioned discipline. There was a perception that strict discipline and obedience to parental authority was a thing of the past and that parents nowadays were more lenient than previous generations. This generational change in discipline methods reflects the expert-guided parenting discourses that advise parents to 'manage' their children's behaviour appropriately (Gambles 2010). Whilst this was widely regarded as a change for the better, several parents felt it had some unintended consequences. Some questioned the effectiveness of the shift and mentioned the need to work out alternative methods to discipline children ,

So there's a lot more explanation that goes on, a lot more talking and there's no smacking... So that's definitely a change for the better... But who knows. Maybe there is too much talking. Maybe kids are just getting too much now. (Caitlyn)

There's probably fashions in parenting and at the moment we're in the not shouting, trying to understand where they're coming from and we're failing dismally [laughs]. (Heidi)

Others felt that some parents were reluctant to discipline their children at all. Some suggested that children were getting away with a lot more, whilst others felt they had less respect for their parents.

I think it's a change for the better, but when you end up with this generation of kids or twenty-somethings that think they deserve everything, I don't know that necessarily that's a good thing. (Heather)

I think that the discipline methods of the past were a lot more effective than they are now. Kids break boundaries all the time now, and they're very much the twentyfirst century lazy slob [laughs]. (Katy)

\section{Greater educational pressures}

The primary focus of the project of which this study was part was the degree to which parents felt obliged to foster their child's learning in the preschool years, a broadening of parents' remit that is both symptomatic of and a contributory factor in the intensification of parenting (Author, 2014). Several parents felt that children faced greater educational pressures nowadays than hitherto and noted a downward shift in the age at which children are expected to undertake a range of educational tasks. Consequently, most parents felt compelled to engage their preschool child in cognitively focused activities at home, including reading and learning letters and numbers to some extent. However, there was great variation in the range of activities parents undertook. It was notable that parents with lower education and income levels were less anxious about promoting children's early learning. Yet many lower-educated parents made a concerted effort to promote their child's early learning precisely because of their own perceived failure to excel academically. 
Only four parents expressed any reservations about or resistance to parental efforts to foster children's learning in the preschool years. For most, it appeared to be an unquestioned facet of their parenting responsibilities. One exception was Amy who was emphatic in her objection to what she termed 'hothousing'. She spoke of the increasing pressure placed on children from kindergarten onwards. Despite not actively 'coaching' her pre-schooler, Amy admitted that her daughter had 'lots of books, and we have read to her a lot, and she's had the opportunity to learn the letters of the alphabet, and the numbers.'

Two other parents also expressed some resistance to the idea of parents deliberately promoting their child's learning in the preschool years, yet both engaged in cognitively focused activities with their child. Caroline described how she and her husband believed that play was more important for preschool-aged children than learning numbers and letters. She said she did not want to be a 'pushy parent' but that she taught her daughter letters and numbers, because she showed an interest. For two parents, a downward shift in the age at which children are expected to undertake a range of educational tasks also related to the idea of preschool as necessary pre-cursor to school: 'Well, when I was a child, we just went straight to kindergarten to prepare for grade one, but now, everybody does the preschool to prepare them for kindergarten.' Reasons given by parents for engaging in cognitively-focussed parenting included: concern about rising educational pressures; that it was a parental obligation; the hope their child might achieve upward social mobility; and concern that their child would be able to maintain their class position in adulthood.

\section{Discussion}

Over the twentieth century, the practise of parenting intensified, morphing from a noun to a verb to underscore how it is no longer conceived of as something one 'is' but rather something one 'does' (Edwards and Gillies 2005, Furedi 2001, Ramaekers and Suissa 2011). The normativity of intensive parenting ideology and the reframing of parenting as a child-centred, expert-guided undertaking transforms it into an activity that parents must learn to perform appropriately. That is, they learn to 'do parenting' according to the tenets of intensive parenting.

This paper aimed to explore how parents' views about changes in childhood influenced the way they 'did parenting'. In doing so, it sought to disentangle the degree to which parents subscribe to intensive parenting ideals or whether other factors could encourage conformity. The interviews highlighted several perceived changes between parents' and their children's childhoods. These were greater child-centeredness, children's lack of an unsupervised public life, changing conceptions of a 'good childhood', discipline and greater educational pressures. These data highlight the socially constructed nature of childhood (Aries 1962, Valentine 2004, James and James 2004, Brannen 2004, Stearns 2003) and demonstrate how perceptions of what is in/appropriate conduct for children and parents is coloured by time, place and dominant discourses concerning 'good parenting'.

These shifts in childhood in turn influenced how these parents 'did parenting', despite their misgivings, and how contemporary parenting standards embody the tenets of Hays' (1996) 'intensive mothering'. Parents referred to risks associated with contemporary childhood that compelled them to adhere to intensive parenting ideals. These included a concern for children's safety if they had unsupervised, free time and a concern for children's future status if they did not receive cognitively focused parenting or attend preschool or structured activities. 
It is widely recognised that all social research is subject to social desirability bias and this is likely enhanced in face-to-face interviews where parents are asked to discuss issues like parenting and childhood. It is possible that inclinations towards social desirability may have encouraged parents to endorse intensive parenting ideals and curtailed criticism. During the discussions, all parents espoused intensive parenting ideals, although when probed further, many were quick to highlight downsides. For these parents, 'doing parenting' according to the tenets of intensive parenting had some negative implications for both children and parents. Parents' irritations with the parenting standards they were upholding are particularly telling and suggestive of a reluctant acceptance of many intensive parenting ideals. At the same time, parents' accounts of differences between their children's childhoods and their own also highlight how the social context within which they 'do parenting' curtails their ability to resist intensive parenting ideals.

Few explicitly drew connections between social context and their parenting practice, however. It was striking that parents were generally unreflective/unquestioning about the way they parented. 'Doing parenting' according to the tenets of intensive parenting ideology was considered normal, natural and a 'legitimate way[-] of organizing social life' (West \& Zimmerman 1987: 146). Few questioned the factors constraining how they parented, with many simply accepting that 'good parents' 'do parenting' in a particular way. However, some expressed frustration with the parenting standards they were expected to meet. Frustrations related to perceptions that child-centred parenting meant children were more indulged than in times past, were unable to cope with disappointment and parents enjoyed less child-free time. Many lamented the fact that their children did not enjoy the unsupervised public life they had experienced, which many felt was detrimental to their child's development. Perceptions of society being more unsafe nowadays led to many parents feeling conflicted about their desire to give their children more freedom, but their sense of obligation to be vigilant. Despite some parents' misgivings about some intensive parenting practices, the perceived risks of non-compliance - fears for children's safety, fears for their children's future and possibly the risks associated with contravening normative expectations of good parenting - served to encourage conformity in how they 'did parenting'.

These findings also point to a number of contradictions in parents' endorsement of intensive parenting ideals. On the one hand, they generally endorsed the changes they identified between their children's childhoods and their own. On the other, many also highlighted downsides to the parenting standards they were expected to uphold. Yet, despite some misgivings, none displayed active resistance to the standards to which they felt accountable, with most dissenters reluctantly subscribing to the tenets of intensive parenting. This conformity, both willing and reluctant, we argue, is promoted in large part by parents' social context. Perceptions that society is (or possibly might be) more unsafe means that children no longer enjoy an unsupervised public life and no longer have the opportunity to entertain themselves away from their parents' watchful gaze. As a result, parents and children are spending more time together and parents feel compelled to fill this time with outings, excursions and structured activities. Despite recognising how the social context of childhood had changed, only one parent explicitly recognised the ramifications this had for how she and others 'do parenting'. These findings demonstrate how shifts in cultural expectations have influenced parenting beliefs and attitudes, but that it is important to also consider how parents' capacity to opt out of intensive parenting ideology is constrained by context. Indeed, the recent finding of 'unsubstantiated child neglect' against parents in the USA for allowing their 10 and 6 year 
old children walk home alone from a local park evinces the 'policing of parenting' and the social forces that encourage conformity to particular parenting standards ${ }^{3}$.

It is well-recognised that the pursuit of intensive parenting practices is a middle-class pre-occupation that demands "middle-class circumstances and resources" (Fox 2006, 243, Aurini and Davies 2005, Chudacoff 2007, Quirke 2006, Vincent 2010). Yet, despite having fewer resources, many low income parents with lower levels of education were committed to intensive parenting ideals. Their drive to provide their children with enriching opportunities matched their more advantaged counterparts; they simply had fewer resources to draw on. Yet it was also the case the lower levels of resources were occasionally associated with less intensive parenting.

A number of limitations of this study must be acknowledged. While the sample comprised a range of education and income levels, cultural and linguistic diversity was limited. Also, only three fathers participated in an interview. Whether this constitutes a limitation of the study or is simply a reflection of the gendered nature of parenting is open to debate. As noted above, social desirability pressures are ever-present in social research and may have influenced parents' accounts. Additionally, the findings reported here are based on qualitative interviews with 29 parents and claims that the findings are representative of the views of all parents of preschool-aged children cannot be made. Nevertheless, this qualitative study provides valuable insights into parents' views on their parenting practices in the age of intensive parenting, insights that would be difficult to achieve through other methods.

As social actors, parents make decisions and hold beliefs that are shaped by cultural norms and standards. How parents 'do parenting' is underpinned by the accountability they feel for behaving in ways consistent with contemporary notions of 'the good parent' which, we argue, align with intensive parenting ideology. These findings are testament to 'the hegemonic power of intensive mothering' (Newman and Henderson 2014, 3) for Australian parents, with most endorsing the increasingly childcentred, labour-intensive, financially expensive and expert-guided character of contemporary parenting. At the same time, the findings demonstrate how this hegemony is reinforced by parents' social context which constrains their ability to challenge or resist the currently dominant intensive parenting ideals. Just as gender can be 'undone' (Risman 2009, West \& Zimmerman 2009), parents could choose not to 'do parenting' in this way. However, in the current study, we found few examples of resistance. Rather, the results suggest that socialisation is still relevant and that contemporary beliefs about proper parenting have become "internalized into preferences or taken-for granted assumptions about courses of action" (England 2011: 117).

\footnotetext{
${ }^{3}$ http://www.washingtonpost.com/local/education/decision-in-free-range-case-does-not-end-debate-about-parenting-andsafety/2015/03/02/5a919454-c04d-11e4-ad5c-3b8ce89f1b89_story.html
} 


\section{References}

Arendell, Terry 1997. "A Social Constructionist Approach to Parenting." In Contemporary Parenting: Challenges and Issues, edited by Terry Arendell. Thousand Oaks, California: Sage.

Aries, Phillipe. 1962. Centuries of Childhood. London: Jonathon Cape.

Aurini, Janice, and Scott Davies. 2005. "Choice without Markets: Homeschooling in the Context of Private Education." British Journal of Sociology of Education no. 26 (4):461-474.

Australian Bureau of Statistics. 2008. Socio-economic Indexes for Areas (SEIFA), Data Cube only, 2006 edited by Australian Bureau of Statistics. Canberra.

Bazeley, Pat. 2009. Analysing Qualitative Data: More Than 'Identifying Themes'. Downloaded from Research Support website. Final copy submitted: Malaysian Journal of Qualitative Research, 2009, 2, 6-22.

Bianchi, Suzanne. M., John P. Robinson, and Melissa A. Milkie. 2006. Changing Rhythms of American Life. New York: Russell Sage Foundation.

Brannen, Julia. 2004. "Childhoods Across the Generations: Stories from women in four-generation English families." Childhood no. 11 (4):409-428.

Bruer, John T. 1998b. "Brain science, brain fiction." Educational Leadership no. 56 (3):14-18.

Bruer, John T. 1999. "In Search of... Brain-Based Education." The Phi Delta Kappan no. 80 (9):648654.

Caputo, Virgina. 2007. "She's from a good family. Performing childhood and motherhood in a Canadian private school setting." Childhood no. 14 (2):173-192.

Carnegie Corporation. 1994. Starting Points: Meeting the Needs of Our Youngest Children. New York: Carnegie Corporation.

Chudacoff, Howard 2007. Children at Play: An American History. New York and London: New York University Press.

Coleman, Marilyn, Lawrence H. Ganong, and Kelly Warzinink. 2007. Family Life in 20th-Century America. Westport, Connecticut \& London: Greenwood Press.

Coltrane, Scott. 2000. Gender and Families. Walnut Creek, CA: Alta Mira Press.

Craig, Lyn. 2006. "Does Father Care Mean Fathers' Share? A Comparison of How Mothers and Fathers in Intact Families Spend Time with Children." Gender \& Society no. 20 (2):259-281.

Cunningham, Hugh. 2006. The Invention of Childhood. London: BBC Books.

Doucet, Andrea. 2006. Do men mother? Fathering, care and domestic responsibility. Toronto: University of Toronto Press.

Doucet, Andrea. 2009. "Gender Equality and Gender Differences: Parenting, Habitus, and Embodiment (The 2008 Porter Lecture)*." Canadian Review of Sociology/Revue canadienne de sociologie no. 46 (2):103-121.

Duncan, Simon, and Rosalind Edwards. 2003. "State welfare regimes, mothers' agencies and gendered moralities." In Thoughts of family, gender, generation and class: a festschrift to Ulla Bjornberg, edited by Kollind K and Peterson A. Goteberg: Sociology Institute.

Edwards, Rosalind, and Val Gillies. 2005. Resources in Parenting: Access to Capitals Project Report. London: South Bank University.

Ehrenreich, Barbara, and Deirdre English. 2005. For Her Own Good: Two Centuries of the Experts' Advice to Women. New York: Anchor House.

Fox, Bonnie. 2006. "Motherhood as a class act: The many ways in which "Intensive Mothering" is entangled with social class." In Social Reproduction: Feminist Political Economy Challenges Neo-Liberalism, edited by Kate Bezanson and Meg Luxton. Montreal \& Kingston, London, Ithaca: McGill-Queen's University Press. 
Furedi, Frank. 2001. Paranoid Parenting. Abandon Your Anxieties and be a Good Parent. London: Allen Lane, The Penguin Press.

Gambles, Richenda. 2010. "Supernanny, parenting and a pedagogical state." Citizenship Studies no. 14 (6):697-709.

Glass, Jennifer. 1998. "Gender liberation, economic squeeze or fear of strangers: Why fathers provide infant care in dual-earner families." Journal of Marriage and the Family no. 60 (4):821-834.

Gornick, Janet, C, and Marcia K Meyers. 2003. Families that Work. Policies for Reconciling Parenthood and Employment. New York: Russell Sage Foundation.

Hays, Sharon. 1996. The Cultural Contradictions of Motherhood. New Haven and London: Yale University Press.

Hulbert, Ann. 2004. Raising America: Experts, parents, and a century of advice about children. New York: Vintage Books.

James, Allison, and Adrian L. James. 2004. Constructing Childhood: Theory, Policy and Social Practice. Basingstoke, Hampshire: Macmillan.

Kociumbas, Jan. 1997. Australian Childhood. A History. St Leonards, NSW: Allen \& Unwin.

Kurz, Demie. 1997. "Doing Parenting: Mothers, Care Work and Policy." In Contemporary Parenting: Challenges and Issues. , edited by Terry Arendell, 92-118. Thousand Oaks: Sage Publications.

Lareau, Annette. 2003. Unequal Childhoods. Class, Race and Family Life. Berkeley, California: University of California Press.

Lareau, Annette. 2011. Unequal Childhoods. Class Race \& Family Life: Second Edition with an Update a Decade Later. Berkeley, Los Angeles, London: University of California Press.

Macvarish, Jan, Ellie Lee, and Pam Lowe. 2014. "The 'First Three Years' Movement and the Infant Brain: A Review of Critiques." Sociology Compass no. 8 (6):792-804. doi: DOI: 10.1111/soc4.12183.

Mannino, Clelia A., and Francine M. Deutsch. 2007. "Changing the Divisions of Household Labour: A Negotiated Process between Partners." Sex Roles no. 56 (5-6):309-324.

Monna, Berenice, and Anna H. Gauthier. 2008. "A review of the Literature on the Social and Economic Determinants of Parental Time." Journal of Family and Economic Issues no. 29 (4):634-653.

Nadesan, Majia Holmer. 2002. "Engineering the Entrepreneurial Infant: Brain science, infant development toys, and governmentality." Cultural Studies no. 16 (3):401-432.

Newman, Harmony D., and Angela C. Henderson. 2014. "The modern mystique: Institutional mediation of hegemonic motherhood." Sociological Inquiry no. 84 (3):472-491.

Nomaguchi, Kei M., Melissa A. Milkie, and Suzanne M. Bianchi. 2005. "Time strains and psychological well-being. Do dual-earner mothers and fathers differ?" Journal of Family Issues no. 26 (6):756-792.

Orloff, Ann Shola. 2009. "Gendering the Comparative Analysis of Welfare States: An Unfinished Agenda." Sociological Theory no. 27 (3):317-343.

Quirke, Linda. 2006. "“Keeping Young Minds Sharp": Children's Cognitive Stimulation and the Rise of Parenting magazines, 1959-2003." The Canadian Review of Sociology and Anthropology no. 43 (4):387-406.

Ramaekers, Stefan, and Judith Suissa. 2011. "Parents as 'educators': languages of education, pedagogy and 'parenting'." Ethics and Education no. 6 (2):197-212.

Sanson, Ann, and Sarah Wise. 2001. "Children and parenting. The past hundred years." Family matters no. 60:36-45.

Sayer, Liana C., Suzanne M. Bianchi, and John P. Robinson. 2004. "Are Parents Investing Less in Children? Trends in Mothers' and Fathers' Time with Children." American Journal of Sociology no. 110 (1):1-43. 
Smith, Alison J. 2004. Who Cares? Fathers and the Time They Spend Looking After Children. In Sociology Working Papers. Department of Sociology, University of Oxford.

Stearns, Peter N. 2003. Anxious Parents. A History of Modern Childrearing in America. New York and London: New York University Press.

Valentine, Gill. 2004. Public Space and the Culture of Childhood. Aldershot: Ashgate.

Vincent, Carol. 2010. "The sociology of mothering." In The Routledge International Handbook of the Sociology of Education, edited by Michael W. Apple, Stephen J. Ball and Luis Armando Gango. London \& New York: Routledge.

Vincent, Carol, and Stephen J. Ball. 2007. "'Making Up' the Middle-Class Child: Families, Activities and Class Dispositions." Sociology no. 41 (6):1061-1077.

Wall, Glenda. 2004. "Is Your Child's Brain Potential Maximized?: Mothering in an Age of New Brain Research." Atlantis no. 28 (2).

Wall, Glenda 2010. "Mothers' experiences with intensive parenting and brain development discourse." Women's Studies International Forum no. 33 (3):253-263

Walzer, Susan. 1998. Thinking about the Baby. Gender and Transitions into Parenthood. Philadelphia: Temple University Press.

Warner, Judith 2005. Perfect Madness: Motherhood in the Age of Anxiety. New York: Riverhead.

West, Candace, and Don. H. Zimmerman. 1987. "Doing Gender." Gender and Society no. 1 (2):125151.

Widding, Ulrika. 2014. "Parenting ideals and (un-)troubled parent positions." Pedagogy, Culture \& Society. doi: 10.1080/14681366.2014.919955.

Wrigley, Julia. 1989. "Do young Children Need Intellectual Stimulation? Experts' Advice to Parents, 1900-1985." History of Education Quarterly no. 29 (1):41-75.

Zelizer, Viviana A. 1985. Pricing the Priceless Child. The Changing Social Value of Children. New York Basic Books, Inc., Publishers. 


\section{University Library}

\section{- M M N E R VA A gateway to Melbourne's research publications}

Minerva Access is the Institutional Repository of The University of Melbourne

Author/s:

Smyth, C;Craig, L

Title:

Conforming to intensive parenting ideals: willingness, reluctance and social context

Date:

2017-03-01

Citation:

Smyth, C. \& Craig, L. (2017). Conforming to intensive parenting ideals: willingness, reluctance and social context. Family Relationships and Society, 6 (1), pp.107-124. https:// doi.org/10.1332/204674315X14393034138937.

Persistent Link:

http://hdl.handle.net/11343/251891 